\title{
Antibacterial and cytotoxicity activities of phenylbutanoids from Zingiber cassumunar Roxb.
}

\author{
Thongchai Taechowisan ${ }^{1 *}$, Savoranee Suttichokthanakorn ${ }^{1}$, Waya S. Phutdhawong ${ }^{2}$ \\ ${ }^{1}$ Department of Microbiology, Faculty of Science, Silpakorn University, Nakorn Pathom 73000, Thailand. \\ ${ }^{2}$ Department of Chemistry, Faculty of Science, Silpakorn University, Nakorn Pathom 73000, Thailand.
}

\begin{tabular}{|c|c|}
\hline ARTICLE INFO & ABSTRACT \\
\hline Article history: & \multirow{5}{*}{$\begin{array}{l}\text { Bioautography was employed as the screening method for purifying bioactive substances of the crude extract of } \\
\text { Zingiber cassumunar Roxb. Purification procedures included silica gel } 60 \text { column chromatography, thin layer } \\
\text { chromatography, and medium pressure liquid chromatography. Identification of purified compounds was achieved } \\
\text { by spectroscopic methods. Three phenylbutanoids were purified and identified as }(E)-3 \text { - }(3,4-\text {-dimethoxyphenyl)- } \\
\text { 4-[(E)-3,4-dimethoxystyryl] cyclohex-1-ene }(\mathbf{1}),(E)-4-(3,4 \text {-dimethoxyphenyl)-but-3-en-1-ol }(\mathbf{2}) \text { and }(E)-4-(3,4- \\
\text { dimethoxyphenyl)-but-3-en-1-yl acetate }(3) \text {. Compound } \mathbf{1} \text { showed high antibacterial activity against Staphylococcus } \\
\text { aureus and Escherichia coli with both MIC }(16 \mu \mathrm{g} / \mathrm{ml}) \text { and MBC }(32 \mu \mathrm{g} / \mathrm{ml}) \text {. These were followed by the MIC } \\
\text { values }(32 \mu \mathrm{g} / \mathrm{ml}) \text { and MBC values }(128 \mu \mathrm{g} / \mathrm{ml}) \text { for compounds } 2 \text { and } \mathbf{3} \text { against the same microorganisms. These } \\
\text { compounds revealed bacteriolytic effects on the assayed strains, causing evident damage to cell walls and membranes } \\
\text { using SYTOX Green. The cytotoxicity activity of purified compounds was determined using MTT colorimetric assay } \\
\text { against L929 and Vero cell lines. They showed weak cytotoxicity activity with } \mathrm{IC}_{50} \text { values of } 1263.42 \text { to } 2857.83 \mu \mathrm{g} / \\
\text { ml and } 1537.83 \text { to } 2698.45 \mu \mathrm{g} / \mathrm{ml} \text { toward L } 929 \text { and Vero cell lines, respectively. }\end{array}$} \\
\hline Received on: 28/03/2018 & \\
\hline Accepted on: $15 / 06 / 2018$ & \\
\hline Available online: $30 / 07 / 2018$ & \\
\hline $\begin{array}{l}\text { Key words: } \\
\text { Antibacterial activity, } \\
\text { cytotoxicity activity, } \\
\text { phenylbutanoids, Plai, } \\
\text { Zingiber cassumunar Roxb. }\end{array}$ & \\
\hline
\end{tabular}

\section{INTRODUCTION}

Zingiber cassumunar Roxb. (Family; Zingiberaceae) is used in folk remedies for the treatment of muscular and joint pain, inflammation, rheumatism, wounds, asthma (Bhuiyan et al., 2008; Chaiwongsa et al., 2012; 2013) in south-east Asia, especially in Thailand. It is known by the Thai name "Plai". The essential oil extracted from the rhizome of $Z$. cassumunar has various active chemical ingredients. These include: $\alpha$ and $\beta$-pinene, $\alpha$ - and $\gamma$-terpinene, limonene, monoterpenes, myrcene, terpinen-4-ol, terpinolene, sabinene, sabmene and phenylbutenoids (Pongprayoon et al., 1997; Bordoloi et al., 1999; Jantan et al., 2003; Bhuiyan et al., 2008). These phytochemicals have various pharmaceutical properties, including, antiinflammatory, anticancer, antifungal, and antioxidant activities (Lu et al., 2008). (E)-4-(3', 4'-dimethoxyphenyl) but-3-en-

\footnotetext{
${ }^{*}$ Corresponding Author

Thongchai Taechowisan, Department of Microbiology, Faculty of Science, Silpakorn University, Nakorn Pathom 73000, Thailand. E-mail: tewson84@gmail.com
}

1-ol is the main phenylbutenoid that exhibits anti-inflammatory activity (Kanjanapothi et al., 1987; Panthong et al., 1990; 1997; Jeenapongsa et al., 2003; Han et al., 2005).

In this study, three phenylbutanoids were isolated from a $Z$. cassumunar extract. This is the first Thai study of their antibacterial activity. Our research was intended to determine the antibacterial activity of phenylbutenoids isolated from a $Z$. cassumunar extract. Sytox green assays provided detailed information on cellular damage and alterations caused by the tested compounds. The results of this study may support the clinical applications of $Z$. cassumunar in treatments for bacterial infections.

\section{MATERIALS AND METHODS}

\section{Plant material and extraction procedure}

Rhizomes of $Z$. cassumunar cultured in Nakhon Pathom, Thailand were collected for use in this study. Fresh rhizomes were washed and chopped into small pieces. Three hundred grams of dry rhizomes were extracted with hexane three times, at room temperature using the maceration method for 3 days. The filtrates 
were pooled and evaporated by rotary evaporator at $40^{\circ} \mathrm{C}$. The crude oil obtained was stored at $4^{\circ} \mathrm{C}$ in dark bottles until it was used in the experiments.

\section{Isolation of the compounds}

The crude extract was dissolved in methanol to perform the bioautography assays (Suleimana et al., 2010). The major compounds were isolated by silica gel 60 (230-400 mesh, Merck) column chromatography and eluted with hexane:ethyl acetate (95:5). Fractions were monitored by thin layer chromatography (TLC) (Kieselgel 60 F254, Merck), and spots were visualized under ultraviolet light and by heating silica gel plates sprayed with $10 \% \mathrm{H}_{2} \mathrm{SO}_{4}$ in ethanol. The combined fractions were eluted with $20-40 \%$ ethyl acetate in hexane by medium pressure liquid chromatography (MPLC) $(400 \times 40 \mathrm{~mm}$ column, Merck LiChroprep Si 60, 25-40 mm, UV-detection, $254 \mathrm{~nm})$ to afford fraction (fr.) A (42 mg), fr. B (59 mg) and fr. C (45 mg). The fr. C had no activity against tested microorganisms. Final purification of fr. A and B was achieved by preparative TLC (Si gel 60, $0.5 \mathrm{~mm}$, Merck) to afford compound $1(31 \mathrm{mg})$ from fr. A and compounds $2(28 \mathrm{mg})$ and $3(21 \mathrm{mg})$ from fr. B. By using infrared, $\mathrm{UV}$ and nuclear magnetic resonance analyses, the chemical structures of these compounds were identical with $(E)-3-(3,4-$ dimethoxyphenyl)-4-[(E)-3,4-dimethoxystyryl] cyclohex-1-ene (1), (E)-4-(3,4-dimethoxyphenyl)-but-3-en-1-ol (2) and (E)-4(3,4-dimethoxyphenyl)-but-3-en-1-yl acetate (3).

\section{Antibacterial assay}

An in vitro plate assay technique was used to test the inhibitory effects of crude extract and purified compounds on the tested bacteria using the paper disk method according to the Clinical Laboratory Standard Institute (CLSI, 2012). Sterile paper discs (6 mm, Whatman 2017-006) were loaded with 50 $\mu \mathrm{l}$ of two-fold dilution of $440 \mathrm{mg} / \mathrm{ml}$ of crude extract or $1 \mathrm{mg} /$ $\mathrm{ml}$ of purified compounds. Four bacterial species were used in this study: S. aureus ATCC25932, Bacillus cereus ATCC7064, E. coli ATCC10536 and Pseudomonas aeruginosa ATCC27853. These bacteria were cultured in nutrient broth at $37^{\circ} \mathrm{C}$ for $24 \mathrm{hrs}$. Dilutions of bacterial suspensions were prepared using McFarland standard tubes $\left(1 \times 10^{8} \mathrm{CFU} / \mathrm{ml}\right)$. The air-dry discs with various concentrations of the crude extract and purified compounds were placed on a lawn of bacterial spread on Muller Hinton agar. The plates were incubated at $37^{\circ} \mathrm{C}$ for $24 \mathrm{hrs}$. The diameter of the formed inhibition zones around each disc was recorded. The experiment was carried out in triplicate using gentamicin (30 unit/ disk) and chloramphenicol (30 $\mu \mathrm{g} /$ disk) (Oxoid, UK) as references for antimicrobial activity control.

\section{Minimum inhibitory concentrations}

The minimum inhibitory concentrations (MIC) of the compound was tested against microorganisms in a 96-well microtiter plate by NCCLS microbroth dilution methods (NCCLS, 2000). The compound was twofold diluted from 0.5 $\mu \mathrm{g} / \mathrm{ml}$ to $512 \mu \mathrm{g} / \mathrm{ml}$ in nutrient broth supplemented with $10 \%$ glucose containing $0.01 \%$ phenol red as a color indicator (NBGP). Bacteria was adjusted to $10^{5} \mathrm{CFU} / \mathrm{ml}$ for each microtiter plate. The microtiter plates were incubated at $37^{\circ} \mathrm{C}$ for $24 \mathrm{hrs}$. Microbial growth was determined by observing the change of color in the wells (red to yellow when there is microbial growth). The lowest concentration that showed no change of color was considered as the MIC. Minimum microbicidal concentration was determined by inoculating onto nutrient agar plates $10 \mu \mathrm{l}$ of the medium from each of the wells from the MIC test which showed no turbidity. The plates were incubated at $37^{\circ} \mathrm{C}$ for $24 \mathrm{hrs}$. Minimum bactericidal concentration (MBC) was defined as the lowest concentration of the test agent at which no microbial growth was observed on the plates.

\section{Sytox green assays}

The assay was performed in microcentrifuge tubes of $0.5 \mathrm{ml}$ final volumes. The crude extract and purified compounds were assayed at the concentration of $10 \mathrm{mg} / \mathrm{ml}$ and $200 \mathrm{mg} / \mathrm{ml}$, respectively. Growth controls replaced samples with sterile water. Five $\mu$ of Sytox green solution were added to the tubes which were incubated at $37^{\circ} \mathrm{C}$ for $1 \mathrm{hr}$. Fifty microliters of samples were placed on glass slides, covered and observed with incident light fluorescence of a Nikon fluorescence microscope (Nikon Fluophot) equipped with an Osram HBO $200 \mathrm{~W} / 2$ mercury vapor lamp. An exciter filter IF 420-490 was used and the photomicrographs were taken using Olympus' cellSens imaging software (version 1.16).

\section{Cytotoxicity activity assay}

In order to evaluate the cytotoxicity activity of the crude extract and purified compounds, cytotoxicity tests were performed and the effect of the median inhibitory dose $\left(\mathrm{IC}_{50}\right)$ on two normal cell lines (L929, murine fibroblast cell line, and Vero, African green monkey kidney cell line) was assessed as previously described (Taechowisan et al., 2017). Briefly, different concentrations $(1,2,4,8,16,32,64,128,256$ and $512 \mu \mathrm{g} / \mathrm{ml})$ of the crude extract and purified compounds were prepared and used in the cytotoxicity tests. To measure the cytotoxicity, $5 \times 10^{4}$ cells were seeded in 96-well plates and incubated in Dulbecco's modified Eagle medium (DMEM) supplemented with 10\% fetal bovine serum containing different concentrations of the test agents at $37^{\circ} \mathrm{C}$ for $24 \mathrm{hrs}$ in a $5 \% \mathrm{CO}_{2}$ incubator. The wells were washed with a serum-free medium. Vehicle control groups were added with double distilled water.

In the tetrazolium salt, 3-4,5 dimethylthiazol-2,5 diphenyl tetrazolium bromide (MTT) assay, yellow MTT was reduced to purple formazan in the mitochondria of viable cells. A quantity of $100 \mu \mathrm{l}$ of the MTT working solution $(0.5 \mathrm{mg} / \mathrm{ml})$ was added to each well and incubated at $37^{\circ} \mathrm{C}$ for $5 \mathrm{hrs}$. Next, the media were removed, wells were washed with phosphate buffer saline, and $100 \mu \mathrm{l}$ of DMSO was added to solubilize the formazan crystalline product. The absorbance was measured using a plate reader (Packard AS10000 Spectrocount, USA) at $590 \mathrm{~nm}$. The production of formazan dye was proportional to the number of viable cells.

The inhibition of cytotoxicity rate of the cell lines for each test agent with different concentrations was calculated according to the following equation:

$\%$ Inhibition $=100-\left[\left(\mathrm{Abs}_{\text {sample }}-\mathrm{Abs}_{\text {blank }}\right) /\left(\mathrm{Abs}_{\text {control }}-\mathrm{Abs}_{\text {blank }}\right)\right] \times 100$,

where $\mathrm{Abs}_{\text {sample }}$ is the absorbance of the test agent and $\mathrm{Abs}_{\text {control }}$ is the absorbance of the control reaction (containing all reagents except 
the test agent). The \%inhibition was plotted against a sample concentration, and a linear regression curve was established in order to calculate the $\mathrm{IC}_{50}$. Tests were carried out in triplicate. Correlation coefficients were optimized.

Table 1: Diameters of inhibition zones of the crude extract and purified compounds on the tested microorganisms.

\begin{tabular}{|c|c|c|c|c|c|}
\hline \multirow{2}{*}{\multicolumn{2}{|c|}{ Test agents/concentrations }} & \multicolumn{4}{|c|}{ Diameters of inhibition zones on tested microorganisms (mm) } \\
\hline & & S.a. ${ }^{a}$ & B.c. & E.c. & P.a. \\
\hline \multirow{4}{*}{ Crude extract } & $2.75 \mathrm{mg} / \mathrm{disc}$ & $\mathrm{NZ}$ & NZ & NZ & $\mathrm{NZ}$ \\
\hline & $5.5 \mathrm{mg} / \mathrm{disc}$ & $\mathrm{NZ}$ & NZ & NZ & $\mathrm{NZ}$ \\
\hline & $11 \mathrm{mg} / \mathrm{disc}$ & $16.68 \pm 2.78$ & $12.26 \pm 2.33$ & $27.70 \pm 3.74$ & $12.35 \pm 1.57$ \\
\hline & $22 \mathrm{mg} / \mathrm{disc}$ & $68.66 \pm 4.95$ & $44.23 \pm 3.86$ & $70.33 \pm 5.78$ & $38.47 \pm 3.13$ \\
\hline \multirow{4}{*}{ Compound 1} & $1 \mu \mathrm{g} / \mathrm{disc}$ & $\mathrm{NZ}$ & $\mathrm{NZ}$ & $\mathrm{NZ}$ & $\mathrm{NZ}$ \\
\hline & $5 \mu \mathrm{g} / \mathrm{disc}$ & $\mathrm{NZ}$ & $\mathrm{NZ}$ & $\mathrm{NZ}$ & $\mathrm{NZ}$ \\
\hline & $10 \mu \mathrm{g} / \mathrm{disc}$ & $23.21 \pm 5.08$ & $17.67 \pm 3.92$ & $27.34 \pm 4.18$ & $15.30 \pm 3.26$ \\
\hline & $50 \mu \mathrm{g} / \mathrm{disc}$ & $54.34 \pm 4.53$ & $38.88 \pm 3.97$ & $53.66 \pm 5.11$ & $33.12 \pm 4.35$ \\
\hline \multirow{4}{*}{ Compound 2} & $1 \mu \mathrm{g} / \mathrm{disc}$ & $\mathrm{NZ}$ & $\mathrm{NZ}$ & $\mathrm{NZ}$ & $\mathrm{NZ}$ \\
\hline & $5 \mu \mathrm{g} / \mathrm{disc}$ & $\mathrm{NZ}$ & $\mathrm{NZ}$ & $\mathrm{NZ}$ & $\mathrm{NZ}$ \\
\hline & $10 \mu \mathrm{g} / \mathrm{disc}$ & $\mathrm{NZ}$ & $\mathrm{NZ}$ & $\mathrm{NZ}$ & $\mathrm{NZ}$ \\
\hline & $50 \mu \mathrm{g} / \mathrm{disc}$ & $30.37 \pm 2.85$ & $14.67 \pm 3.38$ & $31.22 \pm 3.60$ & $10.81 \pm 47$ \\
\hline \multirow{4}{*}{ Compound 3} & $1 \mu \mathrm{g} / \mathrm{disc}$ & $\mathrm{NZ}$ & NZ & $\mathrm{NZ}$ & $\mathrm{NZ}$ \\
\hline & $5 \mu \mathrm{g} / \mathrm{disc}$ & $\mathrm{NZ}$ & $\mathrm{NZ}$ & $\mathrm{NZ}$ & $\mathrm{NZ}$ \\
\hline & $10 \mu \mathrm{g} / \mathrm{disc}$ & $\mathrm{NZ}$ & NZ & $\mathrm{NZ}$ & $\mathrm{NZ}$ \\
\hline & $50 \mu \mathrm{g} / \mathrm{disc}$ & $22.13 \pm 3.82$ & $15.27 \pm 2.47$ & $20.50 \pm 2.66$ & $11.50 \pm 3.33$ \\
\hline Chloramphenicol & $30 \mu \mathrm{g} / \mathrm{disc}$ & $34.61 \pm 1.88$ & $33.23 \pm 1.92$ & $44.31 \pm 1.23$ & $22.15 \pm 1.62$ \\
\hline Gentamicin & $30 \mu \mathrm{g} / \mathrm{disc}$ & $24.92 \pm 1.69$ & $23.53 \pm 1.28$ & $23.53 \pm 1.65$ & $19.38 \pm 1.54$ \\
\hline
\end{tabular}

a.a.; Staphylococcus aureus ATCC25932, B.c.; Bacillus cereus ATCC7064, E.c.; Escherichia coli ATCC10536, P.a.; Pseudomonas aeruginosa ATCC27853.

Results represent the mean \pm SD.

$\mathrm{NZ}=$ No inhibition zone.

\section{RESULTS}

TLC and column chromatography on silica gel was performed with hexane : ethyl acetate as the mobile phase resulted in the separation of three major compounds. Identification of each compound was carried out by ${ }^{1} \mathrm{H}-\mathrm{NMR},{ }^{13} \mathrm{C}-\mathrm{NMR}$ as following.

Compound 1: ${ }^{1} \mathrm{H}-\mathrm{NMR}\left(500 \mathrm{MHz}, \mathrm{CDCl}_{3}\right): 1.68(1 \mathrm{H}$, m), $1.97(1 \mathrm{H}, \mathrm{m}), 2.17(2 \mathrm{H}, \mathrm{m}), 2.24(1 \mathrm{H}, \mathrm{m}), 3.20(1 \mathrm{H}, \mathrm{m}), 3.78$ $(3 \mathrm{H}, \mathrm{s}), 3.80(3 \mathrm{H}, \mathrm{s}), 3.82(3 \mathrm{H}, \mathrm{s}), 3.90(3 \mathrm{H}, \mathrm{s}), 5.64(1 \mathrm{H}, \mathrm{dd}, J=$ $10.0,2.1 \mathrm{~Hz}), 5.86(1 \mathrm{H}, \mathrm{dt}, J=10.0,2.3 \mathrm{~Hz}), 5.98(1 \mathrm{H}, \mathrm{dd}, J=$ $15.9,7.3 \mathrm{~Hz}), 6.03\left({ }^{1} \mathrm{H}, \mathrm{d}, J=15.9 \mathrm{~Hz}\right), 6.66-6.83(6 \mathrm{H}, \mathrm{m}) ;{ }^{13} \mathrm{C}-$ NMR (125 MHz, $\left.\mathrm{CDCl}_{3}\right)$ : $24.9\left(\mathrm{CH}_{2}\right), 28.4\left(\mathrm{CH}_{2}\right), 45.8(\mathrm{CH}), 48.5$ $(\mathrm{CH}), 56.3\left(\mathrm{OCH}_{3}\right), 56.8\left(\mathrm{OCH}_{3}\right), 57.0\left(\mathrm{OCH}_{3}\right), 110.2(\mathrm{CH}), 114.0$ $(\mathrm{CH}), 115.1(\mathrm{CH}), 116.0(\mathrm{CH}), 120.4(\mathrm{CH}), 122.5(\mathrm{CH}), 125,7$ $(\mathrm{CH}), 131.9(\mathrm{CH}), 134.3(\mathrm{CH}), 135.6(\mathrm{CH}), 137.8(\mathrm{C}), 139.8(\mathrm{C})$, 149.6 (C), 150.4 (C), $151.7(\mathrm{C}) . \mathrm{MS}$ m/e: $380.199\left(\mathrm{M}^{+}\right)$(Calcd for $\mathrm{C}_{24} \mathrm{H}_{28} \mathrm{O}_{4}, 380.199$ ). According to literature (Kuroyanagi et al., 1980; Jitoe et al., 1993; Masuda and Jitoe, 1995; Lu et al., 2008), compound 1 was identified as (E)-3-(3,4-dimethoxyphenyl)-4$[(E)$-3,4-dimethoxystyryl] cyclohex-1-ene.

Compound 2: ${ }^{1} \mathrm{H}-\mathrm{NMR}(500 \mathrm{MHz}, \mathrm{CDCl}): 2.61(2 \mathrm{H}$ $\mathrm{q}, J=6.5 \mathrm{~Hz}), 3.72(2 \mathrm{H}, \mathrm{t}, J=6.5 \mathrm{~Hz}), 3.83(3 \mathrm{H}, \mathrm{s}), 3.85(3 \mathrm{H}$, s), $5.58\left({ }^{1} \mathrm{H}, \mathrm{dt}, J=15.5,6.5 \mathrm{~Hz}\right), 6.48\left({ }^{1} \mathrm{H}, \mathrm{d}, J=15.5 \mathrm{~Hz}\right), 6.80$ $(1 \mathrm{H}, \mathrm{d}, J=8.5 \mathrm{~Hz}), 6.90(1 \mathrm{H}, \mathrm{dd}, J=8.5,1.5 \mathrm{~Hz}), 6.92(1 \mathrm{H}, \mathrm{d}, J=$ $1.5 \mathrm{~Hz}) ;{ }^{13} \mathrm{C}-\mathrm{NMR}\left(125 \mathrm{MHz}, \mathrm{CDCl}_{3}\right): 32.8\left(\mathrm{CH}_{2}\right), 56.2\left(\mathrm{OCH}_{3}\right)$, $56.8\left(\mathrm{OCH}_{3}\right), 63.0\left(\mathrm{CH}_{2}\right), 112.2(\mathrm{CH}), 114.2(\mathrm{CH}), 122.0(\mathrm{CH})$, $128.4(\mathrm{CH}), 131.3(\mathrm{CH}), 132.2(\mathrm{C}), 149.8(\mathrm{C}), 150.2(\mathrm{C}) . \mathrm{MS}$ m/e: $208\left(\mathrm{M}^{+}\right)\left(\right.$Calcd for $\left.\mathrm{C}_{12} \mathrm{H}_{16} \mathrm{O}_{3}, 208\right)$. According to literature (Kuroyanagi et al., 1980; Jitoe et al., 1993; Masuda and Jitoe, 1995; Lu et al., 2008), compound 2 was identified as (E)-4-(3,4dimethoxyphenyl)-but-3-en-1-ol.
Compound 3: ${ }^{1} \mathrm{H}-\mathrm{NMR}\left(500 \mathrm{MHz}, \mathrm{CDCl}_{3}\right): 2.10(3 \mathrm{H}$, s), $2.58(2 \mathrm{H}, \mathrm{q}, J=6.5 \mathrm{~Hz}), 3.90(3 \mathrm{H}, \mathrm{s}), 3.96(3 \mathrm{H}, \mathrm{s}), 4.22(2 \mathrm{H}, \mathrm{t}$, $J=6.5 \mathrm{~Hz}), 6.10(1 \mathrm{H}, \mathrm{dt}, J=15.5,6.5 \mathrm{~Hz}), 6.47(1 \mathrm{H}, \mathrm{d}, J=15.5$ $\mathrm{Hz}), 6.86(1 \mathrm{H}, \mathrm{d}, J=8.0 \mathrm{~Hz}), 6.90-6.94(2 \mathrm{H}, \mathrm{m}) ;{ }^{13} \mathrm{C}-\mathrm{NMR}(125$ $\left.\mathrm{MHz}, \mathrm{CDCl}_{3}\right): 21.8\left(\mathrm{CH}_{3}\right), 32.7\left(\mathrm{CH}_{2}\right), 56.0\left(\mathrm{OCH}_{3}\right), 56.5\left(\mathrm{OCH}_{3}\right)$, $64.6\left(\mathrm{CH}_{2}\right), 108.8(\mathrm{CH}), 111.8(\mathrm{CH}), 119.7(\mathrm{CH}), 124.2(\mathrm{CH})$, $130.8(\mathrm{CH}), 133.4(\mathrm{C}), 149.5(\mathrm{C}), 150.2(\mathrm{C}), 172.6(\mathrm{C}=\mathrm{O})$. MS m/e: $251\left(\mathrm{M}^{+}\right)\left(\right.$Calcd for $\left.\mathrm{C}_{24} \mathrm{H}_{28} \mathrm{O}_{4}, 251\right)$. According to literature (Kuroyanagi et al., 1980; Jitoe et al., 1993; Masuda and Jitoe, 1995; Lu et al., 2008), compound 3 was identified as (E)-4-(3,4dimethoxyphenyl)-but-3-en-1-yl acetate.

The structures of these compounds are shown in Figure 1.

The crude extract from $Z$. cassumunar rhizome showed a pale amber color. The crude extract yield was $7.25 \mathrm{ml} / \mathrm{kg}$. The antibacterial activity of the crude extract and purified compounds are summarized in Table 1. Various concentrations of the crude extract and purified compounds were tested using agar disc diffusion assay. A zone of inhibition $>8 \mathrm{~mm}$ in diameter was interpreted as sensitive. All of the susceptible strains were sensitive to the crude extract at 11 to $22 \mathrm{mg} /$ disc. The crude extract showed the highest activity against $E$. coli and $S$. aureus at $22 \mathrm{mg} /$ disc with the average zones of inhibition being $70.33 \pm 5.78 \mathrm{~mm}$ and 68.66 $\pm 4.95 \mathrm{~mm}$, respectively. However, this crude extract showed low activity against $B$. cereus and $P$. aeruginos $a$ at $22 \mathrm{mg} / \mathrm{disc}$ with the average zones of inhibition $44.23 \pm 3.86 \mathrm{~mm}$ and $38.47 \pm 3.13 \mathrm{~mm}$, respectively. Compound 1 showed higher activity than compounds 2 and 3. It also showed the highest activity against $E$. coli and $S$. aureus at $50 \mu \mathrm{g} / \mathrm{disc}$ with the average zones of inhibition being $53.66 \pm 5.11 \mathrm{~mm}$ and $54.34 \pm 4.53 \mathrm{~mm}$, respectively. Compounds $\mathbf{2}$ and $\mathbf{3}$ showed activity against all the tested microorganisms only 
at $50 \mu \mathrm{g} / \mathrm{disc}$, while the compound $\mathbf{1}$ showed prominent activity

containing $2.75-5.5 \mathrm{mg} /$ disc of the crude extract, $1-5 \mu \mathrm{g} / \mathrm{disc}$ of at $10 \mu \mathrm{g} /$ disc. Sensitive results were not obtained with discs compound 1, and 1-10 $\mu \mathrm{g} / \mathrm{disc}$ of compounds $\mathbf{2}$ and $\mathbf{3}$.<smiles>COc1ccc(C=C[C@H]2CCC=C[C@H]2c2ccc(OC)c(OC)c2)cc1OC</smiles><smiles>COc1ccc(/C=C/CCO)cc1OC</smiles>

2<smiles>COc1ccc(/C=C/CCOC(C)=O)cc1OC</smiles>

3

Fig. 1: The chemical structures of the purified compounds; (E)-3-(3,4-dimethoxyphenyl)-4-[(E)-3,4-dimethoxystyryl] cyclohex-1-ene (1), (E)-4-(3,4-dimethoxyphenyl)but-3-en-1-ol (2), (E)-4-(3,4-dimethoxyphenyl)-but-3-en-1-yl acetate (3).

Table 2: Minimum inhibitory concentration (MIC) and minimum bactericidal concentration (MBC) values of crude extract, purified compounds on tested microorganisms

\begin{tabular}{|c|c|c|c|c|c|c|c|c|c|c|}
\hline \multirow{3}{*}{ Test microorganisms } & \multicolumn{10}{|c|}{ Antibacterial activity of the test agents } \\
\hline & \multicolumn{2}{|c|}{ Crude extract $(\mathrm{mg} / \mathrm{ml})$} & \multicolumn{2}{|c|}{ Compound $1(\mu \mathrm{g} / \mathrm{ml})$} & \multicolumn{2}{|c|}{ Compound $2(\mu \mathrm{g} / \mathrm{ml})$} & \multicolumn{2}{|c|}{ Compound $3(\mu \mathrm{g} / \mathrm{ml})$} & \multicolumn{2}{|c|}{ Chloramphenicol $(\mu \mathrm{g} / \mathrm{ml})$} \\
\hline & MIC & MBC & MIC & MBC & MIC & MBC & MIC & MBC & MIC & MBC \\
\hline S.a. ${ }^{a}$ & 1.09 & 2.19 & 16 & 32 & 32 & 128 & 32 & 128 & 4 & 512 \\
\hline B.c. & 8.74 & 34.97 & 64 & 128 & 64 & 256 & 64 & 256 & 8 & $>512$ \\
\hline E.c. & 2.19 & 4.37 & 16 & 32 & 32 & 128 & 32 & 128 & 4 & $>512$ \\
\hline P.a. & 17.49 & 69.94 & 64 & 256 & 128 & 512 & 128 & 512 & 8 & $>512$ \\
\hline
\end{tabular}

aS.a.; Staphylococcus aureus ATCC25932, B.c.; Bacillus cereus ATCC7064, E.c.; Escherichia coli ATCC10536, P.a.; Pseudomonas aeruginosa ATCC27853.

A classification based on MIC values proposed by Algiannis et al. (2001) was used for this study. The extract or the compounds with MIC values up to $512 \mu \mathrm{g} / \mathrm{ml}$ were considered strong inhibitors; with $512 \mu \mathrm{g} / \mathrm{ml}$ as moderate inhibitors; and those above $512 \mu \mathrm{g} / \mathrm{ml}$ as weak inhibitors. Because the crude extract showed MIC values greater than $512 \mu \mathrm{g} / \mathrm{ml}$, it was therefore considered a weak inhibitor against all the test microorganisms. Compound 1 showed the lowest MIC $(16 \mu \mathrm{g} / \mathrm{ml})$ against $S$. aureus and E. coli (Table 2). This was followed by the MIC values (32 $\mu \mathrm{g} / \mathrm{ml}$ ) of compounds $\mathbf{2}$ and $\mathbf{3}$ against the same microorganisms. Compounds 2 and 3 had high MIC values $(128 \mu \mathrm{g} / \mathrm{ml})$ against $P$. aeruginosa. Compound 1 showed the lowest MBC $(32 \mu \mathrm{g} / \mathrm{ml})$ against $S$. aureus and E. coli whereas compounds $\mathbf{2}$ and $\mathbf{3}$ had high MBC values $(512 \mu \mathrm{g} / \mathrm{ml})$ against $P$. aeruginosa. The crude extract has weak inhibitory activity in MBC against $B$. cereus and $P$. aeruginosa. Bacteria exposed to crude extract and purified compounds showed intense fluorescence after Sytox green stain in contrast to control experiments (Figure 2). These findings suggest that these purified compounds exert antibacterial effects by damaging bacterial cell walls and membranes.

To evaluate the cytotoxicity activity of the crude extract and purified compounds against murine fibroblast cells (L929) and African green monkey kidney cells (Vero), the cell lines were incubated with different doses of two-fold dilution $(1-512 \mu \mathrm{g} /$ $\mathrm{ml}$ ) of the crude extract and purified compounds. After $24 \mathrm{hrs}$ of incubation, cell viability was determined by the MTT assay. The crude extract and purified compounds induced cell cytotoxicity in a concentration-dependent manner. The corresponding $\mathrm{IC}_{50}$ 
was calculated, and the results are presented in Table 3. The cytotoxicity activity of the crude extract and purified compounds was observed and showed weak cytotoxicity activity with $\mathrm{IC}_{50}$
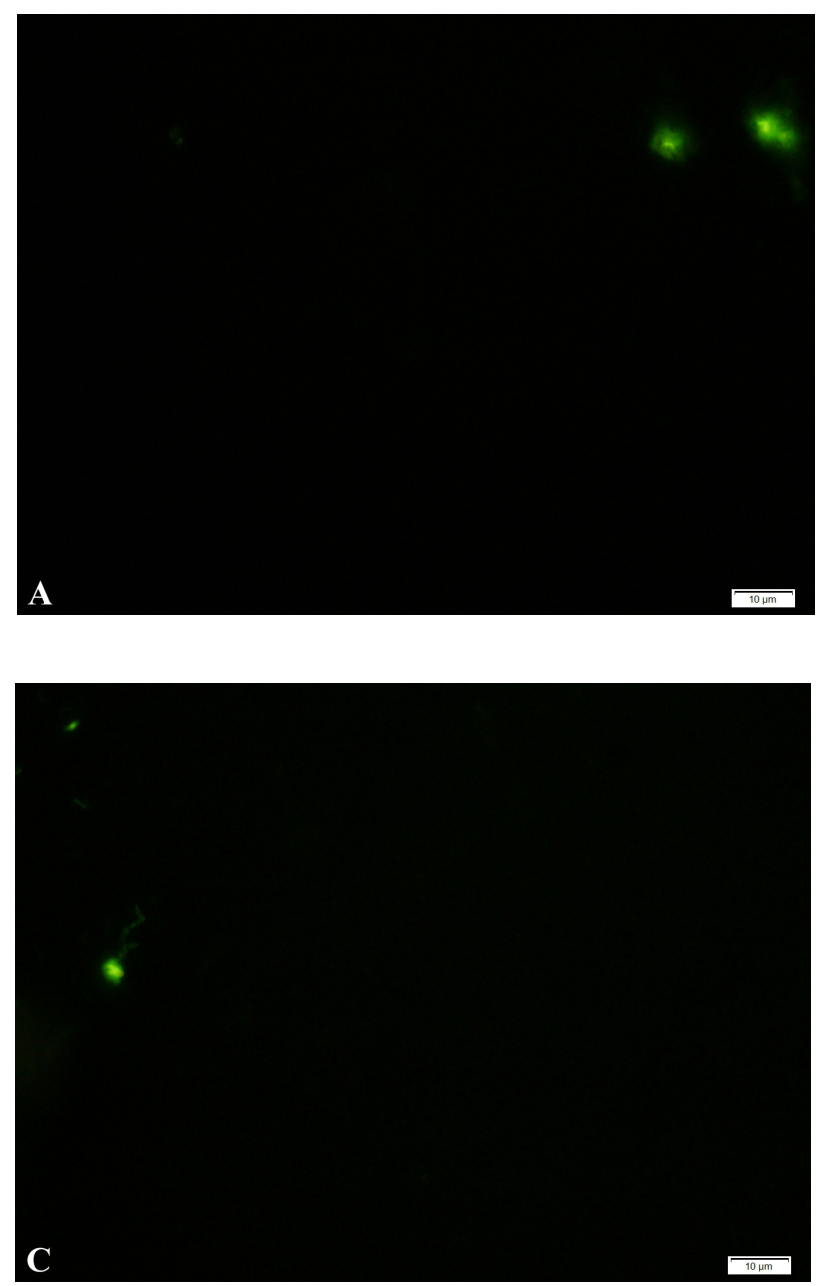

values of 1263.42 to $2857.83 \mu \mathrm{g} / \mathrm{ml}$ and 1537.83 to $2698.45 \mu \mathrm{g} / \mathrm{ml}$ toward L929 and Vero cell lines, respectively.
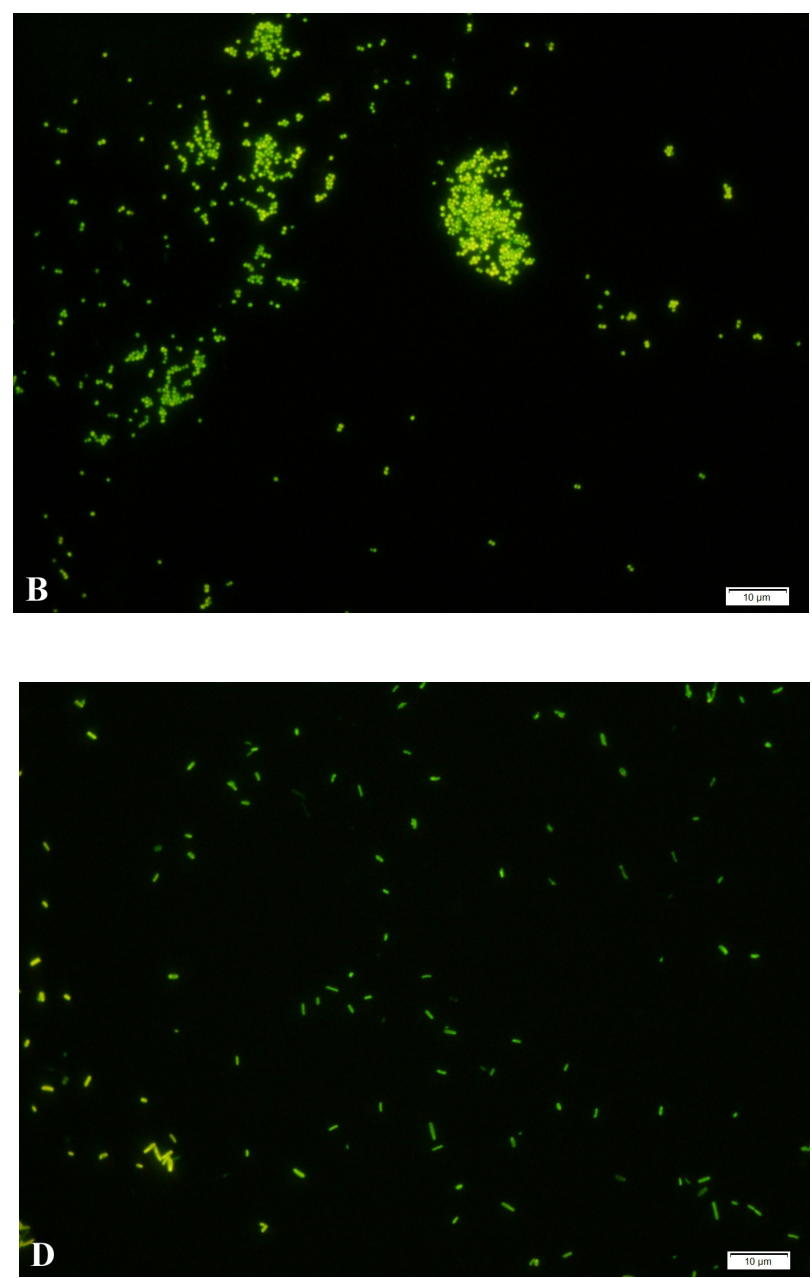

Fig. 2: Sytox green assay. (A) Staphylococcus aureus (control). (B) S. aureus (exposed to compound 1). (C) Escherichia coli (control). (D) E. coli (exposed to compound 1).

Table 3: $\mathrm{IC}_{50}$ of the crude extract, purified compounds against normal cell lines after $24 \mathrm{~h}$ using the MTT assay.

\begin{tabular}{ccc}
\hline \multirow{2}{*}{ Test microorganisms } & \multicolumn{2}{c}{$\begin{array}{c}\mathbf{I C}_{\mathbf{5 0}}{ }^{\text {a }} \text { values of crude extract, purified compounds on } \\
\text { tested cell lines }(\boldsymbol{\mu g} / \mathbf{m l})\end{array}$} \\
\cline { 2 - 3 } & $\mathbf{L 9 2 9}^{\mathbf{b}}$ cells & Vero cells \\
\hline Crude extract & 1483.65 & 1857.16 \\
Compound $\mathbf{1}$ & 1263.42 & 1537.83 \\
Compound $\mathbf{2}$ & 2640.11 & 2481.96 \\
Compound $\mathbf{3}$ & 2857.83 & 2698.45 \\
\hline
\end{tabular}

${ }^{a} \mathrm{IC}_{50}$ values represent the concentration causing $50 \%$ growth inhibition. They were determined by linear regression analysis.

'L929, murine fibroblast cell line; Vero, African green monkey kidney cell line.

\section{DISCUSSION}

Our research findings regarding the major compounds of $Z$. cassumunar from Thailand differ from previous reports in the literature regarding $Z$. cassumunar from other geographical regions. Bhuiyan et al. (2008) reported that the essential oil of
Z. cassumunar rhizome from Bangladesh contain triquinacene 1,4-bis (methoxy), (Z)-ocimene and terpinen-4-ol as the major compounds. Taroeno and Zwaving (1991) found that the $Z$. cassumunar essential oil from Indonesia obtained by extraction with light petroleum had about $46 \%$, with sabinene and terpinen4-ol, trans-1-(3,4-dimethoxyphenyl)but-1-ene, trans-1-(3,4dimethoxyphenyl)butadiene and trans-4-(3,4-dimethoxyphenyl) but-3-ene-1-yl acetate as the main constituents. Z. cassumunar from the northeast of India contained terpinen-4-ol, $\alpha$ - and $\beta$-pinene, sabinene, myrcene, $\alpha$ - and $\gamma$-terpinene, limonene, terpinolene, sabmene and mono-terpenes (Bordoloi et al., 1999). In Malaysia, Kamazeri et al. (2012) reported the rhizome essential oil to contain 2,6,9,9-tetramethyl-2,610-cycloundecatrien-1-one and $\alpha$-caryophyllene as the major compounds. Z. cassumunar from the northern and eastern parts of Thailand contained sabinene, terpinen-4-ol and trans-1-(3,4-dimethoxyphenyl)butadiene as the main component of the rhizome essential oil (Bua-in and Paisooksantivatana, 2009). In this study, therefore, Z. cassumunar essential oil from Thailand was found to have a significantly 
different chemical composition from Z. cassumunar essential oil from other geographical locations. Variations in the chemical composition of the essential oils are known to differ considerably due to the existence of different subspecies. They might also be attributed to other factors such as climate, different regional geographic and seasonal conditions, metabolism of plants, stage of maturity and extraction conditions (Anwar et al., 2009).

In this study, the three phenylbutenoids; were isolated from the $Z$. cassumunar crude extract. These compounds have been reported as the main active components of the essential oil isolated from the hexane extract of $Z$. cassumunar (Amatayakul, 1979). Previous research established, that the phenylbutenoid group is analgesic, anti-inflammatory, antioxidative and anticancer activities (Masuda and Jitoe, 1994; Murakami et al., 2002). These phenylbutenoid compounds have phagocytosis effect that has immunostimulant activity to macrophage cells in the peritoneum of mice (Chairul and Chairul, 2009).

Phenylbutenoid compounds can resist the growth of bacteria. A phenylbutenoid is a derivative from phenol with one or more methoxy substitution. The methoxy group from the phenylbutenoid is the one that possibly interacts with bacteria. The following discussion follows the structure and sequence of a discussion of similar research by Malladi et al. (2017). Both projects investigated the anti-bacterial effects on specific compounds, although the compounds and geographical regions were different, the results were similar. In the present case, as in research previously undertaken by Shah and Desai (2007), the presence of methoxy groups on phenyl group improved the antibacterial activity of purified compounds, a similar observation was reported in isoxazoline derivatives (Shah and Desai, 2007). The antibacterial effects on compounds $\mathbf{2}$ and $\mathbf{3}$ were lower than on compound 1 because phenyl groups include two ortho methoxy. The lower activity was shown by compounds $\mathbf{2}$ and $\mathbf{3}$ against tested bacteria compared to compound $\mathbf{1}$ which can be attributed to the presence of only one dimethoxyphenyl group. The methoxy group affects the charge distribution which significantly improves the biological effect. It is suggested that the increased resistance noted in the presence of methoxy group is likely due to its interaction with some intracellular target. The presence of a strong electronwithdrawing group appears to alter the nature of the compound in some way which facilitates binding to the target(s) (Waring et al., 2002). Highest antibacterial activity was exhibited by the compound having methoxy substitution on two ortho positions.

Highest antibacterial activity was exhibited by the compound having methoxy substitution on two ortho positions. Both electrons withdrawing and donating groups on phenyl group have shown improved antimicrobial activity on the bacterial cells. The better antibacterial activity of compound $\mathbf{1}$ was observed against $S$. aureus and E. coli. Faqroddin et al. (2012) reported that electron releasing groups such as methoxy on 1-(2",4"-dichlorophenyl)-3-(substituted aryl)-2-propene-1-ones displayed maximum antibacterial activity having against Grampositive bacteria (Bacillus subtilis) and Gram-negative bacteria (Escherichia coli). But in this study, both Gram-positive and Gram-negative bacteria have a similar effect, this reason may be that the types of chemical compounds.

Sytox green is a cationic molecule and high-affinity nucleic acid stain that easily penetrates cells with compromised plasma membranes and yet will not cross the membranes of live cells, thus emitting intense green fluorescence after excitation between $450-490 \mathrm{~nm}$ radiations. These properties make Sytox green a suitable indicator for the visualization of both Grampositive and Gram-negative bacteria with damages in cell walls or cell membranes (Langsrud and Sundheim, 1996), as those exposed to phenylbutenoid compounds.

Among the abundant bioactive constituents of $Z$. cassumunar essential oil, some previous studies have shown that sabinene and terpinene-4-ol had antibacterial activities (Wasuwat et al., 1989; Giwanon et al., 2000). They reveal that other compositions in rhizome extract of $Z$. cassumunar are potentially useful in medicines because they exhibit antibacterial activity.

\section{CONCLUSION}

The present study has demonstrated the comparative antibacterial activity of three purified compounds from rhizome extract of $Z$. cassumunar. Compound 1 ((E)-3-(3,4dimethoxyphenyl)-4-[(E)-3,4-dimethoxystyryl] cyclohex-1ene) was the most effective in comparison with the other two compounds, namely compound 2 ((E)-4-(3,4-dimethoxyphenyl)but-3-en-1-ol) and compound 3 ((E)-4-(3,4-dimethoxyphenyl)but-3-en-1-yl acetate). These compounds showed a bactericidal effect against tested bacteria, especially against $S$. aureus and $E$. coli with both MIC and MBC at a concentration of $16 \mu \mathrm{g} / \mathrm{ml}$ and $32 \mu \mathrm{g} / \mathrm{ml}$, respectively. Compound $\mathbf{1}$ showed bacteriolytic effects on the tested strains, causing evident damage to cell walls and membranes.

\section{ACKNOWLEDGMENTS}

This work was supported by the Department of Microbiology, Faculty of Science, Silpakorn University, Thailand.

\section{REFERENCES}

Aligiannis N, Kalpoutzakis E, Mitaku S, Chinou IB. Composition and antimicrobial activity of essential oils of two Origanum species. J Agric Food Chem, 2001; 40:4168-4170.

Amatayakul T, Cannon JR, Dampawan P, Dechatiwong T, Giles RG, Huntrakul C, Kusamran K, Mokkhasamit M, Raston CL, Reutrakul $\mathrm{V}$, White AH. Chemistry and crystal structures of some constituents of Zingiber cassumuar. Aust J Chem, 1979; 32:71-88.

Anwar F, Ali M, Hussain AI, Shahid M. Antioxidant and antimicrobial activities of essential oil and extracts of fennel (Foeniculum vulgare Mill.) seeds from Pakistan. Flavour Fragr J, 2009; 24:170-176.

Bhuiyan NI, Chowdhury JU, Begum J. Volatile constituents of essential oils isolated from leaf and rhizome of Zingiber cassumunar Roxb. Bangladesh J Pharmacol, 2008; 3:69-73.

Bordoloi AK, Sperkova J, Leclercq PA. Essential oils of Zingiber cassumunar Roxb. from Northeast India. J Essential Oil Res, 1999; 11:441445 .

Bua-in S, Paisooksantivatana Y. Essential oil and antioxidant activity of Cassumunar Ginger (Zingiberaceae: Zingiber montanum (Koenig) Link ex Dietr.) collected from various parts of Thailand. Kasetsart J Nat Sci, 2009; 43:467-475.

Chaiwongsa R, Ongchai S, Boonsing P, Kongtawelert P, Panthong A, Reutrakul V. Active compound of Zingiber cassumunar Roxb. down-regulates the expression of genes involved in joint erosion in a human synovial fibroblast cell line. Afri J Tradit Complement Altern Med, 2013; 10:40-48.

Chairul P, Chairul SM. Phagocytosis effectivity test of phenylbutenoid compounds isolated from Bangle (Zingiber cassumunar 
Roxb.) rhizome. Biodiversitas, 2009; 10:40-43.

Chaiwongsa R, Ongchai S, Tangyuenyong S, Prachya Kongtawelert P, Panthong A, Reutrakul V. Chondroprotective potential of bioactive compounds of Zingiber cassumunar Roxb. against cytokineinduced cartilage degradation in explant culture. J Med Plants Res, 2012; 6:5204-5213.

Clinical Laboratory Standard Institute. 2012. Methods for dilution antimicrobial susceptibility tests for bacteria that grow aerobically. Approved standard M7-A9, Wayne, PA, USA: Clinical and Laboratory Standards Institute.

Faqroddin M, Rahaman SA, Moinuddin M. Synthesis and antimicrobial activity of 1-(2',4'-dichlorophenyl)-3-(substituted aryl)-2propene-1-ones. Int J Life Sci Pharm Res, 2012; 2:82-87.

Giwanon R, Thubthimthed S, Rerkam U, Sunthorntanasart T. Antimicrobial activity of terpinen-4-ol and sabinene. Thai J Pharm Sci, 2000; 24(Suppl):27.

Han AR, Kim MS, Jeong YH, Lee SK, Seo EK. Cyclooxygenase-2 inhibitory Phenylbutenoids from the rhizomes of Zingiber cassumunar. Chem Pharm Bull, 2005; 53:1466-1468.

Jantan IB, Yassin MSM, Chin CB, Chen LL, Sim NL. Antifungal activity of the essential oils of nine Zingiberaceae species. Pharm Biol, 2003; 41:392-397.

Jeenapongsa R, Yoovathaworn K, Sriwatanakul KM, Pomgprayoon U.Antiinflammatory activity of (E)-1-(3,4-dimethoxyphenyl) butadiene from Zingiber cassumunar Roxb. J Ethnopharmacol, 2003; 87:143-148.

Jitoe A, Masuda T, Nakatani N. Phenylbutenoid dimers from the rhizomes of Zingiber cassumunar. Phytochemistry, 1993; 32:357-363.

Kamazeri TSAT, Samah OA, Taher M, Susanti D, Qaralleh H. Antimicrobial activity and essential oils of Curcuma aeruginosa, Curcuma mangga, and Zingiber cassumunar from Malaysia. Asian Pac J Trop Med, 2012; 5:202-209.

Kanjanapothi D, Soparat P, Panthong A, Tuntiwachwuttikul $\mathrm{P}$, Reutrakul V. A uterine relaxant compound from Zingiber cassumunar. Planta Med, 1987; 53:329-332.

Kuroyanagi M, Fukushima S, Yoshihira K, Natori S, Dechatiwongse T, Mihashi K, Nishi M, Hara S. Further Characterization of the constituents of a Thai medicinal plant, Zingiber cassumunar Roxb. Chem Pharm Bull, 1980; 28:2948-2959.

Langsrud S, Sundheim G. Flow cytometry for rapid assessment of viability after exposure to a quaternary ammonium compound. J Appl Bacteriol, 1996; 81:411-418.

Lu Y, Liu R, Berthod A, Pan Y. Rapid screening of bioactive components from Zingiber cassumunar using elution-extrusion countercurrent chromatography. J Chromatogr A, 2008; 1181:33-44.

Malladi S, Nadh RV, Babu KS, P. Babu PS. Synthesis and antibacterial activity studies of 2,4-di substituted furan derivatives. BeniSuef Univ J Basic Appl Sci, 2017; 6:345-353.

Masuda T, Jitoe A. Antioxidative and antiinflammatory compounds from tropical gingers: Isolation, structure determination, and activities of cassumunins $\mathrm{A}, \mathrm{B}$, and $\mathrm{C}$, new complex curcuminoids from Zingiber cassumunar. J Agric Food Chem, 1994; 42:1850-1856.
Masuda T, Jitoe A. Phenylbutenoid monomers from the rhizomes of Zingiber cassumunar. Phytochemistry, 1995; 39:459-461.

Murakami A, Takahashi D, Kinoshita T, Koshimizu K, Kim HW, Yoshihiro A, Ohigashi H. Zerumbone, a southeast asian ginger sesquiterpene, markedly suppresses free radical generation, proinflammatory protein production and cancer cell proliferation accompanied by apoptosis: the $\alpha, \beta$-unsaturated carbonyl group is a prerequisite. Carcinogenesis, 2002; 23:795-802.

National Committee for Clinical Laboratory Standards. 2000. Methods for dilution antimicrobial susceptibility tests for bacteria that grow aerobically. Approved standard M7-A5. Wayne, PA, USA: National Committee for Clinical Laboratory Standards.

Panthong A, Kanjanapothi D, Niwatananun V, Tuntiwachwuttikul $\mathrm{P}$, Reutrakul V. Antiinflammatory activity of compounds isolated from Zingiber cassumunar. Planta Med, 1990; 56:655.

Panthong A, Kanjanapothi D, Niwatananun V, Tuntiwachwuttikul P, Reutrakul V. Antiinflammatory activity of compound D ((E)-4-(3',4'dimethoxyphenyl)-but-3-en-2-ol) isolated from Zingiber cassumunar Roxb. Phytomedicine, 1997; 4:207-212.

Pongprayoon U, Tuchinda P, Claeson P, Sematong T. Topical antiinflammatory activity of the major lipophilic constituents of the rhizome of Zingiber cassumunar. Part 1. The essential oil. Phytomedicine, 1997; 3:319-322.

Shah T, Desai V. Synthesis and antibacterial studies of some novel isoxazoline derivatives. J Serb Chem Soc, 2007; 72:443-449.

Suleimana MM, McGaw LJ, Naidoo V, Eloff JN. Detection of antimicrobial compounds by bioautography of different extracts of leaves of selected South African tree species. Afr J Tradit Complement Altern Med, 2010; 7:64-78.

Taechowisan T, Chaisaeng S, Phutdhawong WS. Antibacterial, antioxidant and anticancer activities of biphenyls from Streptomyces sp. BO-07; an endophyte in Boesenbergia rotunda (L.) Mansf A. Food Agri Immunol, 2017; 28:1330-1346.

Taroeno Brophy JJ, Zwaving JH. Analysis of the essential oil of Zingiber cassumunar Roxb. from Indonesia. Flavour Fragr J, 1991; 6:161164.

Waring MJ, Ben-Hadda T, Kotchevar AT, Ramdani A, Touzani R, Elkadiri S, Hakkou A, Bouakka M, Ellis T. 2,3-Bifunctionalized quinoxalines: synthesis, DNA interactions and evaluation of anticancer, anti-tuberculosis and antifungal activity. Molecules, 2002; 7:641-656.

Wasuwat S, Wanisorn P, Mahintorntep B, Kuwaono K, Sanghirun S. Studies on antimicrobial and antifungal activities of terpinen-4-ol extracted from Zingiber cassumunar Roxb. Thailand Institute of Scientific and Technological Research, Research Project No. 30-32/Rep. No.1; 1989 (In Thai).

How to cite this article:

Taechowisan T, Suttichokthanakorn S, Phutdhawong WS. Antibacterial and cytotoxicity activities of phenylbutanoids from Zingiber cassumunar Roxb. J App Pharm Sci, 2018; 8(07): 121127. 